\title{
The Filipino virtue ethics in Wojtyla's sexual ethics: An academic response to Reyes
}

\author{
De Leon, Rodney Mari S. $\triangle$ \\ De La Salle University, Philippines (Rodney_mari_deleon@dlsu.edu.ph)
}

Canete, Jonathan James O.

De La Salle University / Lasalle College of Antipolo, Philippines (Ncanete976@ gmail.com)

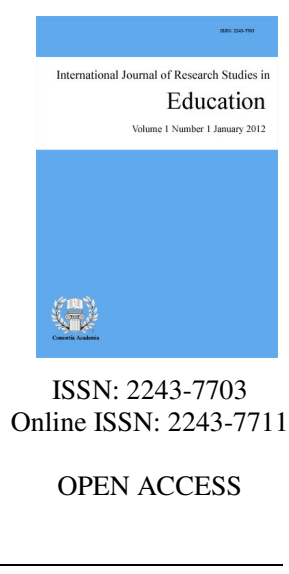

Received: 30 March 2021

Revised: 7 July 2021

Accepted: 15 July 2021 DOI: $10.5861 /$ ijrse. 2021.691

\section{Abstract}

In Jeremiah Lasquety-Reyes' two (2) papers, he made a case for the existence of a "Filipino virtue ethics." He argued that relationship-oriented virtue ethics that is 'Filipino' exists and that it is a product of mixing both the Spanish Catholic tradition and Southeast Asian tribal tradition. He presented it through a dialogue with Aristotelian-Thomistic virtue ethics. $\mathrm{He}$ revolved on two (2) Filipino concepts as the basis of his exposition - loob (inner-self), kapwa (significant other/ brethren), and all other virtues or aspects flow from these two (2) foundational concepts. He also argued for the case of hiya (shamefulness) as a virtue, rather than a mere passion or emotion, in his other paper. Overall, the main point of his introductory paper on Filipino virtue ethics is that its main feature is that it aims to maintain and improve human relationships. Filipino virtue ethics is not individualistic but relationship-based, and its end goal is pagkakaisa or the 'oneness' concept in Filipino. He also noted that this Filipino relationship-centered virtue ethics is relevant even beyond the Philippines, especially in the midst of an individualistic world. So, this reply paper aims to compare this Filipino virtue ethics to Wojtyla's Personalistic-Thomistic sexual ethics found in his groundbreaking work, "Love and Responsibility," and see the manifestations of Filipino virtue ethics in it. Filipino virtue ethics and Wojtyla's Personalistic-Thomistic sexual ethics contain certain similarities, such as their emphasis on interpersonal relationships, valuing the 'other,' and self-restraint.

Keywords: Filipino, virtue ethics, sexual ethics, Wojtyla, Reyes 


\section{The Filipino virtue ethics in Wojtyla's sexual ethics: An academic response to Reyes}

\section{Introduction}

Jeremiah Lasquety-Reyes $(2015,2016)$ made a case for the existence of a "Filipino virtue ethics" in his two (2) papers, "Loob and Kapwa: An Introduction to a Filipino Virtue Ethics" and "In Defense of Hiya as a Filipino Virtue." He argued that relationship-oriented virtue ethics that is 'Filipino' exists and that it is a product of mixing both the Spanish Catholic tradition and Southeast Asian tribal tradition. To better understand or illustrate the concepts, he used Thomistic- Aristotelian virtue ethics to expound further on the meaning of those concepts. He started with a glossary of terms or concepts in his Filipino virtue ethics, such as loob, kapwa, kagandahangloob, utang-na-loob, pakikiramdam, hiya, and lakas-ng-loob/bahala na - Lakas-ng-loob. Overall, all these concepts are rooted in loob and kapwa, which are the foundational concepts of this Filipino virtue ethics. Furthermore, all these concepts involve emphasis on preserving and maintaining interpersonal relationships.

However, this Filipino virtue ethics lack an exposition on sexual/conjugal relations between man and woman, despite its emphasis on preservation and enhancing relationships. Nevertheless, despite the lack of such, these concepts in themselves can be applied in the context of sexual ethics too. Therefore, the use of Karol Wojtyla's sexual ethics in his work, Love and Responsibility, is deemed appropriate in this study. The reason behind the selection of his sexual ethics, out of all ethical philosophies, is due to its similarities to this Filipino virtue ethics, such as its emphasis on relationships, self-restraint, and valuing the human person. Hence, this paper aims to analyze how these concepts in Filipino virtue ethics can be found in Wojtyla's sexual ethics. By uncovering the manifestations of these concepts in Wojtyla's, the scope of Filipino virtue ethics would be all the more expounded, most especially in the realm of sexual ethics.

\section{Discussion}

\subsection{Filipino Virtue Ethics}

Loob is translated as 'inside,' but in the context of virtue ethics and when talking about a person, it does not merely talk about his/her literal 'insides.' Rather, it talks more about one's core of personhood, which he/she is, or the person's 'will,' which is also one of the known English translations of it (De Castro, 1998). However, Reyes prefers to use the term 'relational will' to express its meaning better. This is obviously due to the relational nature of this concept, which would not give justice to the concept if it is discussed in isolation. Loob is the concept that enables one to determine the kind of person an individual is, but it can only be determined based on one's actions, mainly through one's relationship with his/her kapwa (literally "others"; a concept to be discussed further in the next paragraph). Reyes used the Thomistic concept of "potential" to illustrate the meaning of loob. For example, in the case of a seed, it has the potency (potential) to become a tree, but this potency can only be actualized once it finally becomes a tree. So, in a way, one can say that the tree has been "inside" the seed all along, only that it has to be actualized first in order for one to conclude. It is through the act that potency is actualized.

Similarly, 'will' too is a potential of the soul and only manifested through actions. Now apply this concept or analogy to loob, which, if we recall, is also translated as 'will.' Loob is also manifested or actualized through one's actions. However, it does not stop there because it is not based on mere actions alone. More accurately, loob is manifested through one's actions towards others or his kapwa. In other words, through a person's actions towards his/her kapwa and how he/she lives his/her relationship or interacts with them, one's loob is revealed. Conversely, "I" would know a person's loob (or who he/she is as a person) based on how he/she treats me when I am at the receiving end of his actions. What must be emphasized here is relationships. Hence Reyes preferred to translate it as 'relational will.' Loob is only determined by how a person interacts with their kapwa. Kapwa, 
concerning the previous paragraph, is the other essential and foundational concept in this Filipino virtue ethics. First of all, it must be noted that loob cannot be justly defined and understood without kapwa. Kapwa is translated as 'the other' or 'others.' However, as noted by Enriquez (1992), the Filipino concept of kapwa is different from 'others' because he believes that kapwa is the "unity of the self and others" (p. 52). From this, we can further see the relational nature of kapwa, compared to the individualistic 'self' and 'others' conception, and in fact, Reyes' preferred translation of kapwa is 'together with the person,' which does not give focus to the 'I/self' at all. Simply put, kapwa is a Filipino concept denoting unity between two persons. Reyes then explained further the "Filipino virtues," which all are grounded on the concepts of loob and kapwa. He again used Thomistic-Aristotelian virtues to compare them with Filipino virtues to illustrate their meaning better. He used the virtues of 'charity and 'justice. As an analogy for two (2) Filipino virtues: kagandahang-loob and utang-na-loob. Charity and justice are the two virtues in the will (Disputed Questions on Virtue, Q.1, A. 5), and they are both directed towards another, which could be God or another person. On the other hand, their respective counterparts in Filipino virtue ethics, which are charity and justice, as mentioned, are also found in the 'will,' or more accurately, in the loob, which is "the only part of the soul that Filipino virtue ethics is concerned with” (Reyes, 2015, p. 158).

Magandang-loob is translated as 'beauty-of-will.' This virtue is manifested through acts of kindness or generosity towards others. However, it does not stop there. For an act of kindness or generosity to be kagandahang-loob, it should stem from pure and good intentions from the person, not to expect something in return or any other ulterior motive. The person must also not be acting under external compulsion (De Castro, 1998). Furthermore, it must also be understood that the animistic-tribal origins of these virtues also come into play because, in tribal traditions, they naturally help one another for the sake of survival. Like our own families, it would be natural to help them when they are in need. The same goes for kagandahang-loob, wherein a person treats the other with kindness and generosity because of good intentions. One should consider him/her as part of one's family/group. This is where the 'tribal' or family-oriented mindset of the Filipino thought also comes into play and the Catholic-Christian influence, where an individual is called to 'love' others, our kapwa. Although kagandahang-loob is similar to charity, Reyes further clarifies that it is more of the Thomistic virtue of 'benevolence' rather than charity because kagandahang- loob is more often shown towards someone in need or someone from a superior state to an inferior state. On the other hand, charity is directed to the person's significant other, but God is obviously not 'inferior' to human beings and does not actually 'need' humanity's love. Thus, the love we show to God is 'charity' but not kagandahang-loob because it is His love towards us, kagandahang-loob. The "superior to inferior" is seen in the examples Reyes gave, such as a man buying a beggar some food, giving money to a friend whose father is in the hospital to pay his bills, a father applying to become an OFW so he can support his family, or the love of a mother to an infant. Although Aquinas also clarifies that one person who, in a sense, superior to another, may also be inferior to another to a different extent, so thus, Reyes concluded that kagandahang-loob is still possible to be shown in any situation between two (2) human beings.

Utang-na-loob is translated as 'debt of will.' This virtue is the Filipino concept which states that if a person does something good to us, it would be natural for us to do something good to that person in return, as a form of gratitude or giving back. To be more precise, if a person shows us an act of kagandahang-loob, we would then have an utang-na-loob to that person, and thus, we would owe that person a kagandahang-loob when he/she is in need. This is often commonly manifested in the family, wherein in Filipino society, children are expected to be eternally grateful to their parents for giving them life and for all the efforts they have made to raise them (Holnsteiner, 1973). That is why it is common for Filipinos to take care of their parents still when they grow old, rather than leaving them alone or sending them to a nursing home because they have tremendous utang-na-loob to their parents. Utang-na-loob can also be shown outside the family context, such as when one person got rushed to the hospital due to an accident. It is his companion or friend who rushed him and paid for his hospital bills. Once that person recovers, he then has an utang-na-loob towards that friend of his. When the time comes that his friend would be the one in need, that person would (or should) go the extra mile in helping him too, and 
thus, his utang-na-loob would finally be translated into a kagandahang-loob to that friend, and it is now the friend who has an utang-na-loob to him. However, it must be clarified that utang- na-loob is not something imposed by another person but somewhat expected to be self-imposed and self-binding. One should be free from external compulsion and ulterior motives (Reyes, 2015; De Castro, 1998; and Miranda, 1987). Like kagandahang-loob, utang-na-loob is all about maintaining and strengthening relationships with others, not for 'transaction purposes.' As articulated by Reyes, "to have utang-na-loób means that one values kapwa relationships and seeks to prolong and strengthen these relationships. For Filipino virtue ethics, healthy kapwa relationships are ends in themselves and sources of happiness" (p. 161). That is why in Filipino society, it would be worst to be called 'Walang utang-na-loob,' which means someone who has received kagandahang-loob from others but does not repay or acknowledge it. This kind of attitude may destroy relationships with others.

On the other hand, another Thomistic-Aristotelian virtue has an equivalent in Filipino virtue ethics, and that is 'prudence.' And its counterpart is the virtue of pakikiramdam (sensitivity). Prudence is the virtue that allows a person to find the 'middle way' based on one's rational judgment (Summa Theologiae II-II, Q.46, A. 7). Similarly, pakikiramdam also tries to find a 'middle way,' but the main difference is that this is not rooted in a mere intellectual judgment, but through empathy or sensitivity but through empathy or sensitivity. Pakikiramdam is translated as 'feeling,' but Reyes prefers to call it 'relational sensitivity' or 'empathy' towards one's kapwa. Suppose prudence is based on the faculty of reason, which makes it cognitive. In that case, pakikiramdam is more affective (Mataragnon, 1987), so it is more precisely translated as 'empathy.' Pakikiramdam is manifested when a person tries to determine his/her kapwa's feelings or state of emotions not through rational judgment but empathy. Thus, the person would decide how to best act or respond to that kapwa, given the situation. It is a form of empathy or sensitivity which goes beyond direct communication or even nonverbal cues. In other words, it is when "someone tries to read the other person's inner state without the help of words or direct communication" (Reyes, 2015, p. 163). Reyes used jokes as an example to illustrate its meaning further or introduce this concept. Before a person decides to tell a joke, he/she should feel and determine whether that joke would make a successful impact on the audience or understand or accept it. Once a person delivers the joke successfully and makes them laugh, it strengthens the intimacy, and if the joke is even more obscure yet makes an impact, the greater the intimacy. To deliver a joke successfully, one must incorporate the right tone of voice, facial expression, gestures and feel the perfect timing to deliver it. Furthermore, this can only be determined through pakikiramdam. Emotions, empathy, or affection genuinely play a massive role in Filipino culture, and this is also seen in lambing and tampo. Lambing is an exaggerated form of affection, while tampo is a form of being upset or sulking. Nevertheless, when these two (2) are expressed, the other person is expected to figure out what the person is expressing or feeling. If that other person figures it out, it shows emotional sensitivity or empathy, and he/she is expected to feel how to best respond to that person. In other words, he knows how to show pakikiramdam.

Hiya is also discussed both as a 'passion' and as a 'virtue' by Reyes (2015), most especially in his other paper, "In Defense of Hiya as a Filipino Virtue," written in 2016, where he made a more apparent distinction between 'hiya as a passion' and 'hiya as a virtue.' Hiya is translated as 'shame' or 'embarrassment.' However, this translation does not distinguish between the 'passion' and the 'virtue.' To distinguish the two, Reyes used hiya(p) to refer to 'hiya as passion.' In contrast, hiya(v) is used to refer to 'hiya as a virtue,' so I will be using the same designations to distinguish both. Hiya(p) is the negative or painful emotion felt when embarrassed. For example, in a gathering, if somebody publicly exposed an embarrassing secret of mine, and "I" feel embarrassed, that feeling of embarrassment or 'shame' is hiya(p). However, that instant could have been prevented as well if that somebody had hiya(v). From here, one can see that hiya(v) is a virtue which is somewhat akin to 'temperance' or 'self-restraint.' In the Thomistic-Aristotelian concept, temperance is the virtue that enables a person to practice self-restraint, particularly when it comes to one's natural desires (especially on food, drink, and sex). Hiya(v), however, is not achieved by merely restraining one's desires. Instead, it is a practice of self-restraint or sacrifice of one's desire for the good of one's kapwa. As stated by Reyes, an example of this can be seen when Filipinos are dining as a group. In such lunch or dinner gatherings, if the last piece of the food (e.g., chicken, pizza) is left 
on the table, it is common for them to feel hesitant to take it for themselves because others might want or need it. What makes them hesitant to eat the last piece is hiya(v). This only gets resolved once the host gets to pick who eats the last piece, saying, "Wag ka na mahiya." Another instance is, for example, I meet with a friend somewhere to catch up. After our meet-up, if he offers me a ride home using his car, I would naturally first refuse, saying, "Wag na, nahiya naman ako sa'yo" (No need, I would feel bad/concerned for you). This is because, in this theoretical context, my house is too far from his route. While I do have the desire to go home comfortably, because of hiya(v), I controlled my desire for the welfare of my friend, who is my kapwa. Furthermore, Reyes (2016) gave another definition of hiya(v). He said that hiya(v) is also defined as "a virtue of a person that prevents other people from suffering hiya(p)" (p. 69). This is manifested in the case of someone restraining himself/herself from saying something insulting about a person in public so that that person will not feel shame or hiya(p), in connection to the first example stated in this paragraph. What prevented someone from saying such is his hiya(v). Overall, based on these two definitions, we can see that hiya(v) is not merely a form of mere self-restraint for the sake of one's self, but rather, self-restraint for the welfare of one's kapwa. That is why another negative expression in Filipino is the term Walang-hiya, which means that someone is only thinking about himself/herself, only wanting to satisfy his/her impulses or desires, without thinking about the welfare of one's kapwa. It is a lack of sensitivity to another person; that is why one would prefer to go about how he/she wants to act or say something. Overall, we can see that from all the virtues discussed, it all revolves around one's loob and kapwa. How one acts reveals one's loob and how he/she wants to maintain relationships with their kapwa. This shows the relational nature of Filipino virtue ethics, unlike the Thomistic- Aristotelian virtues each was compared to. While the terms may be synonymous, the Thomistic-Aristotelian concepts primarily focus on the self alone, but the Filipino virtue ethics concepts emphasize the importance of maintaining and preserving relationships.

\subsection{Wojtyla's Sexual Ethics}

Karol Josef Wojtyla, who eventually became Pope St. John Paul II, is a 20th-century Catholic priest, pope, philosopher, and theologian who has dedicated much of his life composing a robust collection of writings and reflections on the topic of human sexuality, particularly sexual ethics or morality, as well as the relationship between the two (2) sexes, man and woman. He was born in Poland years before WWII. He grew up in a Nazi-occupied and Soviet-occupied Poland, in which he very much saw how these ideologies violated the 'dignity of the human person.' A few of his notable works on the topic of human sexuality are "Love and Responsibility," "The Theology of the Body," "Mulieris Dignitatem," and "Veritatis Splendor." As Aguas (2014) elaborated, Wojtyla's ethical philosophy is grounded on Thomistic ethics, but he is also influenced by phenomenology, particularly by Max Scheler's. His ethical philosophy is a synthesis of the metaphysical realism of Aristotle and Thomas Aquinas and the sensitivity to the human experience of Scheler's phenomenology. While using them as a starting point for his phenomenology and personalism, he at the same time criticizes Scheler's ethics. He also criticized Kant's approach to ethics for refusing to take into the human experience of the human act. Nonetheless, Wojtyla credits him as well alongside Scheler for the development of his ethical philosophy. Therefore, his ethical philosophy considers not just the moral rule or principle an act follows but also the person's experience itself and the virtues practiced.

"Love and Responsibility," among his many other works, encapsulates very well his ethical or moral philosophy on the topic of human sexuality. This book was written and published in 1960, the same decade where the Sexual Revolution in the West started. One can reasonably conclude that his sexual ethics is the antithesis to the sexual revolution mostly inspired by hedonistic, utilitarian, and second-wave feminist principles. The principles of his sexual ethics are rooted in the concept of a 'person': that man and woman is a 'person,' and that only a person is capable of "love" and they ought to be "loved" and not to be used. Drawing from Boethius and Aristotle's definition, he argues that human beings are 'persons' with a rational nature (cognition) and free will, which sets them apart from the animal species who only live by instinct. But he goes beyond the Aristotelian notion of humans (initially, "man" only) being merely "rational animals." He posits that the human 
person is the one who exists and acts. He further defines the 'person' as "an objective entity, which as a definite subject has the closest contacts with the whole (external) world and is most intimately involved with it precisely because of its inwardness, its interior life" (p. 23). The "interior life" is defined as the "spiritual life" involving truth and goodness.

In the context of sexual relations, Wojtlya (1960) notes that man is not only the subject but can also be the object of an action. In the case of the two sexes engaging in a sexual act, the man is the subject while the woman is the object of the action, and at the same time, the woman is the subject while the man is the object. Therefore, the responsibility or accountability of action, in general, lies on both. The prominent position of Wojtyla on the morality of sexual acts can be encapsulated in one statement from his book: "A person's rightful due is to be treated as an object of love, not as an object for use" (p. 42). He further gives two (2) definitions of the word "use": (1) to employ the object of action as a means to an end, and (2) to experience a pleasure. Hence, given his claim that persons should never be used as a mere means to an end, he then argues that 'love' is what will preclude the possibility of a man utilizing a woman (and vice-versa) as a mere means to an end. Love, he defines, is when two people consciously choose to pursue a common end, provided that it is an excellent end to which they subordinate themselves. He also further elaborates that 'love' is a mutual relationship between two people (in the context of sexual relations, man and woman) and is not merely defined by 'attraction' or 'desire.' However, he recognizes that those two elements are a part of it and are the starting points to which it is achieved. Love ultimately is defined as an act of goodwill in which one wills the good for the other. It is not merely dependent on emotions, attraction, or desire. These concepts are rooted in the "personalistic norm" (p. 41), as he calls it. The "personalistic norm" states that the person is a "good towards which the only proper and adequate attitude is love" (p. 41) and that the person "does not admit of use and cannot be treated as an object of use and as such the means to an end" (p. 41). It can also be seen here that he criticizes the hedonistic, utilitarian principle of pleasure being the highest good and using the other as a means to maximize pleasure.

Applying this in the context of sexual relations, the only way a man and a woman can eliminate the possibility of them merely using each other is when they both agree to pursue the immediate good end of the sexual act, procreation. This end, however, must be achieved. Once man and woman are in the context of 'betrothed love' or 'marital love,' a kind of love that goes beyond attraction, desire, or goodwill. Wojtyla defines the essence of 'betrothed love' as "self-giving, the surrender of one is I" (p. 96). The kind of married love that a man and a woman must possess, furthermore, must be in line with the 'personalistic norm,' in which it must embody "reciprocal self-giving, a mutual betrothed love" (p. 99). "Self-giving," however, does not merely apply in the context of sexuality but also holistically. Otherwise, if it is only understood sexually, it still risks falling into utilitarian attitudes. Wojtyla, however, does not merely argue that procreation is the mere and sole purpose of the sexual act. Though he defines it as the primary end, he also states that the conjugal act's purpose is also to unite two human persons, in other words, two "I's" into one "we," rooted in their mutual betrothed love. He also criticized rigorous or puritanical (procreation only) and 'libidinistic' (pleasure only) interpretations of the sexual urge. All of these personalistic, sexual ethical principles of Wojtyla can be summed up or simplified through the Christian virtue of 'chastity.' Contrary to common misconception, chastity is not 'prudishness' or 'puritanism' (which Wojtyla himself criticized). It does not treat sexual desire as something 'evil' nor 'immoral' either. Instead, drawing from Aquinas, chastity is best understood as the efficient control of the concupiscent impulses set up by the sensual and emotional reactions. Chastity is the crucial ability not only to subdue the impulses originating from the senses and emotions; it is the ability to permanently keep the sensual appetites in equilibrium employing its habitual attitude to the true good determined by reason (Aguas, 2014, p. 256). Wojtyla also emphasized, "the essence of chastity consists in quickness to affirm the value of the person in every situation, and in raising to the personal level all reactions to the values of 'the body and sex"' (p. 171). In other words, it is through the virtue of chastity where one can genuinely affirm the value of the human person (the opposite sex), aspire to the person's true good, and unite in a common good. To sum up, Wojtyla's sexual ethics is anchored on the "personalistic norm," which posits that "persons" must not be a mere means to an end or means to pleasure and thus must be "loved." Furthermore, through love, particularly betrothed love, the couple consciously chooses 
to pursue its proper ends, which will preclude the possibility of reducing the person into a mere means of pleasure. All of these are achieved through a proper understanding and application of the virtue of 'chastity' in the context of sexual relations between the two sexes.

\subsection{The Filipino Virtues in Wojtyla's Sexual Ethics}

Now that these two (2) ethical philosophies have been laid out, we can see that what is typical between Filipino virtue ethics and Wojtyla's sexual ethics emphasizes human relationships. Both of them give importance to relationships between or among human persons. Wojtyla tells us to value the 'dignity of the human person through the virtue of 'love,' while Filipino virtues tell us to treat one another as our kapwa by practicing those virtues. The main difference between the two, however, is that Filipino virtue ethics all about human relationships in general, regardless of sex, but for Wojtyla's sexual ethics, it, of course, only emphasizes the conjugal or sexual relations between the two (2) sexes: man and woman. In Wojtyla's other writings, of course, he also talked about enhancing human relationships outside the context of sexual relations, particularly in his 'Theory of Participation' (citation here). So it can also be said that the manifestation of Filipino virtues can be found in those writings. However, this paper would like to focus and limit its scope only on his sexual ethics found in 'Love and Responsibility.' It is also good to point out that the Filipino virtue ethics of Reyes does not contain anything about the virtue of 'chastity' or even about the conjugal relations between the two (2) sexes. He only focused on cultivating relationships among persons through those virtues outside the context of sexual relations. However, despite this, the researchers argue that it is still possible for the virtue of chastity to be incorporated in Filipino virtue ethics. Through dialogue with Wojtyla's sexual ethics, can this be possible? The researchers chose Wojtyla out of all ethical philosophies because of its similarities with Filipino virtue ethics, particularly its emphasis on human relationships. Both of them have a touch of Thomistic-Aristotelian virtues. That is why in this section, we will see how the Filipino virtues are present or manifested in Wojtyla's sexual ethics.

First, the researchers would like to mention that Reyes himself also quoted Wojtyla to explain what loob is. As stated in the first section of this paper, how a person treats another reveal what his/her loob is. If a person practices kindness to his kapwa, that is a manifestation of kagandahang-loob, and thus his loob is maganda (good). This is similar to what Wojyla (1979) said in his work, "The Acting Person," where he stated that "Action reveals the person; Action gives one the best insight into the inherent essence of the person and allows us to understand the person most fully" (p. 11). Now let us connect these concepts with Wojtyla's principles in "Love and Responsibility." Recall that one of the main principles of his sexual ethics is that a person must not be treated as an object of "use," but rather an object of love. A person is "used" when he/she is reduced to a mere means of sexual pleasure, which is what happens when two (2) people (regardless of sex) engage in sexual acts outside the bounds of marriage. The only way a man and a woman can preclude the possibility of being "used" is that if they both agree to pursue the immediate good end of the sexual act, which is procreation, within the bounds of 'marital love,' that is. Alternatively, in a non-married man and woman, the possibility is precluded if they choose to abstain and be chaste in moments of sexual temptation. In the two examples mentioned above, one can see a decision to do something for the other, which is good. Instead of giving in to one's selfish sexual desires to use the other person as a means for sexual pleasure, both decided to direct their sexual energies in their proper direction, mainly through the virtue of chastity. Their real intentions are then revealed from their actions, and we can see what kind of person they are. Applying the concepts of Filipino virtue ethics, we now see the loob of those two persons because of their chosen actions. Instead of using the other person of the opposite sex, their kapwa, for their selfish desires, they instead chose to value their dignity as human persons by being chaste. We can see that they have a "beautiful" or "good" loob, and the decision to "love' the other (by being chaste) can arguably be considered a manifestation of kagandahang-loob too. This is because the decision to be chaste is an act of 'benevolence' or 'love' for the other; rather than taking advantage of the opportunity to use the person for sexual pleasure, the man decided to value the woman's dignity instead.

Furthermore, if the man's intentions to be chaste are all pure, without ulterior motive and without expecting 
something in return, and is motivated by the desire to preserve the relationship. All the more, can this case be arguably considered a manifestation of kagandahang-loob. We cite the specific example of a teenage couple, boyfriend, and girlfriend. If the boyfriend decides to abstain and be chaste, rather than inviting his girlfriend to perform sexual acts, he just did an act of valuing the dignity of his girlfriend as his kapwa. Moreover, if he believes that being chaste is what would preserve his relationship with her much better and the way to real 'love,' then all the more, we can see that the act of chastity can also be considered kagandahang-loob. In the context of a married couple, too, utang-na-loob can also be found to a minimal extent. We recall that for Wojtyla, when a man and a woman choose to marry each other and participate in the conjugal act, they are no longer two "I's" but one "we." In other words, due to the self-giving nature of mutual betrothed love, they become united in one flesh. Furthermore, as stated above, "self-giving" does not only apply to the context of the conjugal act but also in their marriage as a whole. So, therefore, in their life as a married couple, as they do acts of 'love' or kagandahang-loob to each other, as husband and wife, as their fellow kapwa, there also comes a natural inclination for both of them to "return the favor" by constantly choosing to love each other again and again, without measure, all for the sake of maintaining, enhancing, and preserving their relationships as a married couple, which is precisely the point of utang-na-loob. It is also good to note that utang-na-loob does not have a "limit" or a "measurement." It is done as much as one can do so, not for the sake of mere transaction or getting something from the other, but again, mainly for the sake of preserving the relationship. That is why Wojtyla also pointed out that 'self-giving' still risks falling into utilitarian attitudes if it is only applied in the context of sexual acts and not holistically. Wojtyla also emphasized that 'reciprocity' in the context of love is not necessarily selfish because it would always depend on what the man and the woman bring into the relationship. Furthermore, if both bring the virtue of 'love' in the relationship, that is a form of healthy reciprocity. So here, we can see how utang-na-loob is still applied to a minimal extent.

Pakikiramdam, on the other hand, mainly applies to the discernment of one's feelings or emotions, especially when discerning 'love.' Wojtyla wrote that there are many forms of emotions or phenomena that are often mistaken to be "love." Sometimes mere 'attraction' and 'desire' could be mistaken by either the person feeling it or the object of it, or both, as well as 'sentimentality' or 'sensuality.' These are often felt when a man and a woman are still courting each other, and discerning whether they are meant to be together for marriage or not. Therefore, in this discernment process, pakikiramdam in one sense is present too, because as one enters in a relationship, one should be able to feel very well and discern what exactly is he/she feeling for that person and what is that person's feeling or desire towards the other. Even though Wojtyla gives importance to reasoning or intellect, he never left 'emotions' out of the equation. He even recognized that emotions are indeed part of 'love' and can be the starting point, which he elaborated in the "Psychological Analysis of Love" section of his work. Although he emphasizes in the end that 'love' ultimately has to do with a person's choice and willingness to do what is best for the other, valuing the person as a human person, and not because of his/her sexual value alone. Now going back to the emotions part, when a person starts to experience the feeling of infatuation, attraction, as well as sentimentality and sensuality, he/she should know how to pakiramdam (feel/discern) what would be the best course of action to take, and how to respond to the object of one's emotions, even without the other explicitly stating what one should do. In other words, this situation is also an example of applying prudence, which is the closest counterpart of pakikiramdam in Thomistic- Aristotelian virtues. Thus, this is where pakikiramdam can be seen manifested in Wojtyla's sexual ethics.

Lastly, hiya can also be found in Wojtyla's sexual ethics, both passion, and virtue. Wojtyla dedicated a subchapter to discuss the phenomenon of 'sexual shame.' He stated that it is natural for one (both man and woman, in different levels) to 'conceal' one is sexual values because of 'shame.' Wojtyla defined 'shame' as "a tendency, uniquely characteristic of the human person, to conceal sexual values sufficiently to prevent them from obscuring the value of the person as such" (p. 187). In other words, the purpose of 'sexual shame,' which persons naturally feel, is to prevent the possibility of them being used as an object of pleasure. Wojtyla further explained that the virtue of modesty also flows from 'shame,' as seen in its definition. This phenomenon explains why people (not just Filipinos) have the natural tendency to conceal sexual organs or sexual values to protect 
themselves, and this is where we can see that this tendency is not only rooted in 'fear' alone but also in our innate tendency to protect ourselves from revealing that we are human persons and not objects for use. Now one might be led to ask where can hiya as passion and virtue be found in Wojtyla's exposition of sexual shame. The feeling of 'shame' that a person feels whenever he/she feels the need to conceal sexual values can both be hiya(p) and hiya(v). This can be an instance of hiya(p) because this is partly rooted in 'fear,' the fear of the possibility of being reduced to an object of pleasure. Nevertheless, at the same time, this can also be hiya(v), mainly if this instance is where the person chose to conceal them and be modest because it is a case where the person has discerned that it would be imprudent to expose one's sexual values merely. After all, he/she might lead others to sexual arousal. Furthermore, the person may have also felt that if another person would see his/her sexual values, that other person would feel 'shame,' too, or hiya(p). Hence, it is an instance of a person showing hiya(v) because he/she does not want another to feel hiya(p). Also, going back to the example mentioned in one of the previous paragraphs, in the case of the unmarried couple, boyfriend and girlfriend, the boyfriend choosing to have abstained and be chaste, rather than engaging in a sexual act with his girlfriend, is a manifestation of hiya(v) too. This is because he chose to sacrifice his desires for the welfare of his girlfriend. Furthermore, it could also be because he does not want his girlfriend to experience the hiya(p) or the sexual shame of engaging in a pre-marital sexual act. In other words, since hiya(v) is a form of self-restraint like the virtue of temperance (where the virtue of chastity flows from as well), a person choosing to be modest and be chaste is an example of hiya(v) because he chose to sacrifice and restrain his desires for the sake of others, and to prevent others from feeling hiya(p).

\section{Conclusion}

Overall, one can see how the aforementioned Filipino virtues are very much evident in Wojtyla's sexual ethics in "Love and Responsibility." The two (2) ethical philosophies similar are their emphasis or focus on interpersonal relationships and self-restraint. Nevertheless, noticeably, the Filipino virtue ethics expounded upon by Reyes lacks any mention of the virtue of chastity, nor does it touch upon the sexual relations between man and woman. That is why the authors of this paper chose Wojtyla's sexual ethics as the philosophy to be used to see if these Filipino virtues can also be applied in the context of sexual relations.

As Reyes stated, this Filipino virtue ethics goal is pagkakaisa or 'oneness,' in other words, unity. Similarly, Wojtyla's sexual ethics' goal is to achieve an authentic form of unity between the two (2) sexes through the virtue of chastity, and thus, in society too, where chaste love would be the foundation. By analyzing the manifestations of Filipino virtues in Wojtyla's, all the more can the relevance of Filipino virtues in the conversation of ethics be highlighted and have more to offer in this individualistic and increasingly hedonistic-utilitarian world, especially when it comes to sexual values. While the researchers acknowledge the limitations of this paper and admit that this is not an exhaustive study on Filipino virtue ethics and Wojtyla yet, it is the researchers' profound hope that this paper would further lead to more studies expounding on Filipino virtue ethics, most especially on sexual ethics, not only in comparison to Wojtyla's but also to other ethical philosophies.

\section{References:}

Aguas, J. J. (2014). Person, action, and love: The philosophical thoughts of Karol Wojtyla (John Paul II). Manila: UST Publishing House.

Aquinas, T. (1888-1906). Summa Theologiae. In Commissio Leonina (Ed.), Opera omnia iussu impensaque Leonis XIII P.M. edita (Vols. 4-12). Rome: Typographia Polyglotta.

Aquinas, T. (2010). Disputed questions on virtue. (J. Hause, \& C. Murphy, Trans.). Indianapolis, IN: Hackett Publishing Company.

De Castro, L. D. (1998). Debts of goodwill and interpersonal justice. Retrieved from http://www.bu.edu/wcp/Papers/Asia/AsiaDeCa.htm

Enriquez, V. (1992). From colonial to liberation psychology. Quezon City: The University of the Philippines Press. 
De Leon, R. M. S., \& Canete, J. J. O.

Miranda, D. (1987). Pagkamakatao: Reflections on the theological virtues in the Philippine context. Manila: Divine Word Publications.

Reyes, J. (2016). In Defense of Hiya as a Filipino Virtue. Asian Journal of Philosophy, 26(1), 66-78. https://doi.org/10.1080/09552367.2015.1136203

Reyes, J. (2015). Loob and Kapwa: An Introduction to a Filipino Virtue Ethics, Asian Journal of Philosophy, 25(2), 148-171. https://doi.org/10.1080/09552367.2015.1043173

Wojtyla, K. (1979). The acting person. Dordrecht: D. Reidel Publishing Company.

Wojtyla, K. (1960). Love and responsibility. California: Ignatius Press.

70 Consortia Academia Publishing (A partner of Network of Professional Researchers and Educators) 